\title{
Separation of Concanavalin A-induced Human Suppressor and Helper T Cells by the Autologous Erythrocyte
} Rosette Technique

\author{
Tsuyoshi Sakane, Masaaki Honda, Yoshio Taniguchi, and \\ Hiroyuki Kotani, Department of Internal Medicine, \\ Shimane Medical University, Izumo, Shimane, 693, Japan
}

A B S TRACT Very few normal human peripheral blood $\mathrm{T}$ cells are capable of binding autologous erythrocytes to form rosettes, whereas in the $T$ cell population activated by concanavalin $\mathrm{A}$ (Con $\mathrm{A}$ ) the autorosette levels are markedly enhanced. Fractionation of the Con A-activated T cells with autologous erythrocytes into autorosetting and nonrosetting cells demonstrates that suppressor, but not helper, activity resides in the autorosetting population, whereas the reverse is true of the nonrosetting population. Both these activities are found to be Con A dependent. The Con A-induced human suppressor cells can be identified and separated from the Con A-induced human helper cells by the autorosette technique.

Studies on the surface properties of autorosetting and nonrosetting $\mathrm{T}$ cells indicate that there is little correlation between the activated suppressor and helper $\mathrm{T}$ cell subsets defined by autorosette technique and either those defined by monoclonal antibodies (which are able to distinguish these subsets in the resting but not activated $\mathrm{T}$ cells) or those defined by $\mathrm{Fc}_{\mathrm{c}}$ receptors. Since the autorosetting $T$ cell population (which acts as suppressor cells) bears receptors for peanut agglutinin, the nature of Con A-induced human suppressor cells appears to be analogous to that of Con A-induced murine suppressor cells.

\section{INTRODUCTION}

Concanavalin A (Con A) ${ }^{1}$ activation of peripheral $\mathrm{T}$ lymphocytes in mice can induce both helper and sup-

A preliminary report of this work was presented at the Fourth International Congress of Immunology, 24 July 1980.

Received for publication 26 August 1980 and in revised form 6 April 1981.

${ }^{1}$ Abbreviations used in this paper: Con A, concanavalin A; HBSS, Hanks' balanced salt solution; MLR, mixed lymphocyte reaction; PNA, peanut agglutinin; PWM, pokeweed mitogen; RBC, erythrocytes. pressor function $(1,2)$. There is evidence that these two effects are mediated by two separate $T$ cell populations expressing different Ly components (2). Human peripheral blood $\mathrm{T}$ cells can be also activated by Con $\mathrm{A}$ to become suppressor cells, but not to exert detectable helper effects (3). Based on animal studies, one can assume that $(a)$ Con A-activated human T cell population contains both suppressor and helper cell types; the helper effect might be masked by the suppressor effect. (b) Specific markers can be expressed on the Con A-induced human suppressor T cells and/or helper $T$ cells.

Our approach to these questions involves the use of a technique of rosette formation with autologous erythrocytes (RBC). Normally there is a population of human peripheral blood $\mathrm{T}$ cells capable of binding autologous RBC to form rosettes (4). Approximately $3 \%$ of fresh or unstimulated $\mathrm{T}$ cells incubated at $37^{\circ} \mathrm{C}$ form rosettes with autologous RBC; autorosette levels are much higher in the $\mathrm{T}$ cells stimulated by Con $\mathrm{A}$ (4). In this report we examine the regulatory functions and the surface properties of the Con A-activated autorosetting and nonrosetting $\mathrm{T}$ cell populations.

\section{METHODS}

Isolation of $T$ cells, $B$ cells, and monocytes. Peripheral blood mononuclear cells of normal individuals were isolated and $T$ and $B$ cells separated by the sheep RBC rosette technique as described previously (5). Doubly purified rosetting $T$ cells were recovered after lysis of sheep RBC by hypotonic shock. These $\mathrm{T}$ cell preparations consisted of $>95 \% \mathrm{~T}$ cells as determined by rerosetting. Doubly purified nonrosetting cells were depleted of monocytes by removal of cells adhering to petri dishes. Monocytes were obtained by collecting the cells adhering firmly to the dishes. The percent of $T$ cell contamination in the nonadherent, nonrosetting $B$ cell population was $<1 \%$ as determined by rerosetting. More than $95 \%$ of "monocyte" preparations were monocytes as judged by morphology after Giemsa staining. 
Con A activation of $T$ cells. Con A-activated cultures were established in $17 \times 100-\mathrm{mm}$ plastic tubes (Falcon Labware, Div. Becton, Dickinson Co., Oxnard, Calif.) and consisted of $4 \mathrm{ml}$ of culture medium, RPMI 1640 (Flow Laboratories Inc., Rockville, Md.) supplemented with $10 \%$ heat-inactivated fetal bovine serum (Flow Laboratories) containing $4 \times 10^{6}$ purified $\mathrm{T}$ cells and $3 \times 10^{5}$ mitomycintreated monocytes. These cultures were incubated at $37^{\circ} \mathrm{C}$ in a $5 \% \mathrm{CO}_{2} / 95 \%$ air humidified environment in the presence or absence of $40 \mu \mathrm{g}$ of Con A (Pharmacia Fine Chemicals, Div. Pharmacia, Inc., Piscataway, N. J.). 60 h later the cells were harvested, treated with $0.1 \mathrm{M} \alpha$-methyl-D-mannoside (Sigma Chemical Co., St. Louis, Mo.) in Hanks' balanced salt solution (HBSS) for $30 \mathrm{~min}$ at room temperature, washed four times, and tested for their ability to form rosettes with autologous $\mathrm{RBC}$ or for their regulatory activities in the test cultures (see below).

Autorosette formation and separation of autorosettes. $2 \times 10^{6} \mathrm{~T}$ cells (fresh $\mathrm{T}$ cells, $\mathrm{T}$ cells precultured with or without Con A) in $0.2 \mathrm{ml}$ HBSS, $0.2 \mathrm{ml}$ of fetal bovine serum, and $0.5 \mathrm{ml}$ of $2.5 \%$ autologous RBC in HBSS (prewashed three times in HBSS) were mixed thoroughly and incubated at $37^{\circ} \mathrm{C}$ for $10 \mathrm{~min}$. The mixture was then centrifuged at $150 \mathrm{~g}$ for $5 \mathrm{~min}$ and incubated on ice for $2 \mathrm{~h}$. The cells were gently resuspended for either counting the autorosettes, or for their separation on Ficoll-Hypaque gradients. At least 300 lymphocytes were counted and $\mathrm{T}$ cells binding three or more autologous RBC were regarded as autorosette-forming cells. For separation, the autologous RBC-T cell suspension was layered over Ficoll-Hypaque, centrifuged at $400 \mathrm{~g}$ for $20 \mathrm{~min}$ at $4^{\circ} \mathrm{C}$, and rosetting cells and nonrosetting cells were collected separately. The pelleted rosette-forming cells were resuspended in cold HBSS and further purified on another Ficoll-Hypaque gradient. The rosetting fraction obtained had $\geqq 95 \%$ autorosettes. Autologous RBC in this fraction were lysed by hypotonic shock. The nonrosetting population was rerosetted with autologous RBC exactly as described above and recentrifuged over Ficoll-Hypaque. This purification procedure gave a fraction containing only $1 \%$ autorosettes.

Test cultures for assay of activities of Con A-activated $T$ cells. In all experiments, responder lymphocytes and monocytes in test cultures were obtained $3 \mathrm{~d}$ later from the blood of the same individual who originally provided the Con A-activated $\mathrm{T}$ cells.

For assay of suppressor activity, the $\mathrm{T}$ cells precultured with Con A (unfractionated and fractionated with autologous RBC) were first treated with mitomycin and tested for their suppressive ability in the test culture system. $5 \times 10^{4}$ mitomycin-treated $\mathrm{T}$ cells from Con A-activated culture were added to the test cultures of $5 \times 10^{4}$ responder cells plus 2,500 mitomycin-treated monocytes (3), and stimulated with either allogeneic cells (mixed lymphocyte reaction, MLR) or pokeweed mitogen (PWM). Where $\mathrm{T}$ cells were used as responder cells in the test culture, they were stimulated with $5 \times 10^{4}$ mitomycin-treated allogeneic cells. When B cells were used as responder cells, PWM $(1 \mu \mathrm{g} / \mathrm{ml}$; Grand Island Biological Co., Grand Island, N. Y.) was the stimulant in the culture. Because the $B$ cell response to PWM is clearly $T$ cell dependent (6), freshly prepared autologous $\mathrm{T}$ cells that had been treated with mitomycin were also added $\left(5 \times 10^{4}\right.$ per culture). All cultures were performed in triplicate of $0.2 \mathrm{ml}$ in microtiter plates (Cooke Engineering Co., Alexandria, Va.) and incubated for $144 \mathrm{~h}$ at $37^{\circ} \mathrm{C}$ in a $5 \%$ $\mathrm{CO}_{2} / 95 \%$ air humidified environment. The proliferative response was measured by incorporation of $\left[\right.$ methyl $\left.-{ }^{3} \mathrm{H}\right]$ thymidine ( $2 \mathrm{Ci} / \mathrm{mmol}$; New England Nuclear, Boston, Mass.) during the last $20 \mathrm{~h}$ of culture $(3,5)$. The degree of sup- pression was calculated with the following formula: percentage of suppression $=(1-[$ mean counts per minute of stimulated cultures containing responder cells and $\mathrm{T}$ cells from Con A-activated culture - mean counts per minute of unstimulated cultures containing responder cells and $T$ cells from Con A-activated culture]/[mean counts per minute of stimulated cultures containing responder cells alone - mean counts per minute of unstimulated cultures containing responder cells alone] $) \times 100$.

For assay of helper activity, $\mathrm{T}$ cells from Con A-activated culture were used as helper cells in the PWM-stimulated culture of B cells. $5 \times 10^{4}$ mitomycin-treated T cells from Con A-activated culture (unfractionated or fractionated cells) were introduced into the test cultures of $5 \times 10^{4}$ responder B cells and 2,500 mitomycin-treated monocytes, and stimulated with $1 \mu \mathrm{g} / \mathrm{ml} \mathrm{PWM}$. These test cultures were incubated for $144 \mathrm{~h}$ at $37^{\circ} \mathrm{C}$ and the proliferative response was evaluated by thymidine incorporation.

Surface markers on $T$ cell subpopulations. Con Aactivated $\mathrm{T}$ cell subpopulations obtained by the autorosette technique were analyzed with a series of monoclonal antibodies reactive with peripheral $\mathrm{T}$ cells (OKT3), inducer/ helper $\mathrm{T}$ cells (OKT4), and cytotoxic/suppressor $\mathrm{T}$ cells (OKT8) (Ortho Pharmaceutical Corp., Raritan, N. J.). OKT3 ${ }^{+}$, $\mathrm{OKT}^{+}$, and $\mathrm{OKT}^{+}{ }^{+}$cells were determined by indirect immunofluorescence using fluorescein isothiocyanate-conjugated rabbit anti-mouse IgG (Miles Laboratories, Inc. Miles Research Products, Elkhart, Ind.) with a fluorescence microscope (Nihon kogaku Inc., Tokyo, Japan). T cells bearing receptors for the $\mathrm{Fc}$ portion of IgG ( $\mathrm{T} \gamma$ cells) were detected by using the preferential ability of $\mathrm{T} \gamma$ cells to form rosettes with ox RBC sensitized with rabbit IgG antibody to the RBC (7). Cells bearing receptors for peanut agglutinin (PNA) were identified by the fluorescence staining technique with fluorescein isothiocyanate conjugated PNA (EY Laboratories, Inc., San Mateo, Calif.).

\section{RESULTS}

Effect of Con A stimulation on autorosette formation. The $\mathrm{T}$ cell autorosette levels of 30 normal individuals were studied. Very few fresh $\mathrm{T}$ cells and $\mathrm{T}$ cells that had been incubated for $60 \mathrm{~h}$ in the absence of Con A were capable of binding autologous RBC to form rosettes (mean percentage of autorosettes with the standard error, $3.0 \pm 0.5$ and $1.0 \pm 0.3$, respectively). In contrast, when T cells were precultured for $60 \mathrm{~h}$ with Con $\mathrm{A}$ at an optimal concentration, the rosette levels were strongly enhanced $(30.0 \pm 2.7 \%)$. This mean percent was significantly different $(P<0.001)$ from that of both fresh $\mathrm{T}$ cells and $\mathrm{T}$ cells precultured without Con A.

The increase in the autorosette levels was most likely not due to a nonspecific binding of the RBC to Con A molecules on the cell surface, for the following reasons: (a) neither B lymphocytes nor monocytes can form autorosettes even after Con A activation; (b) exposure of $\mathbf{T}$ cells to the optimal dose of Con A for $2 \mathrm{~h}$ did not increase the autorosetteforming cell levels; $(c)$ inclusion, before rosetting, of $\alpha$-methyl-D-mannoside, a competitive inhibitor of Con A activation, did not influence the autorosette levels of Con A-activated $\mathrm{T}$ cells. These data provide strong 
evidence that the increase in autorosette levels observed in the Con A-activated T cells is attributable to the Con A activation itself.

Suppressor activities of Con A-activated $T$ cells forming autorosettes and those not forming autorosettes. Con A-activated $\mathrm{T}$ cells were fractionated with autologous RBC into the cells forming autorosettes and cells not forming autorosettes. The fractionated $T$ cells were assayed for their ability to mediate suppression of $\mathrm{T}$ cell proliferative response to MLR or B cell proliferative response to PWM (Fig. 1). We found that unfractionated $T$ cells that had been activated by Con A led to suppression of both reactions. Con A-activated autorosetting $\mathrm{T}$ cells gave more suppression of both reactions. In contrast, the $T$ cells not forming autorosettes gave no demonstrable suppression, and were added to the test cultures only to increase both reactions. This suppressor $\mathrm{T}$ cell

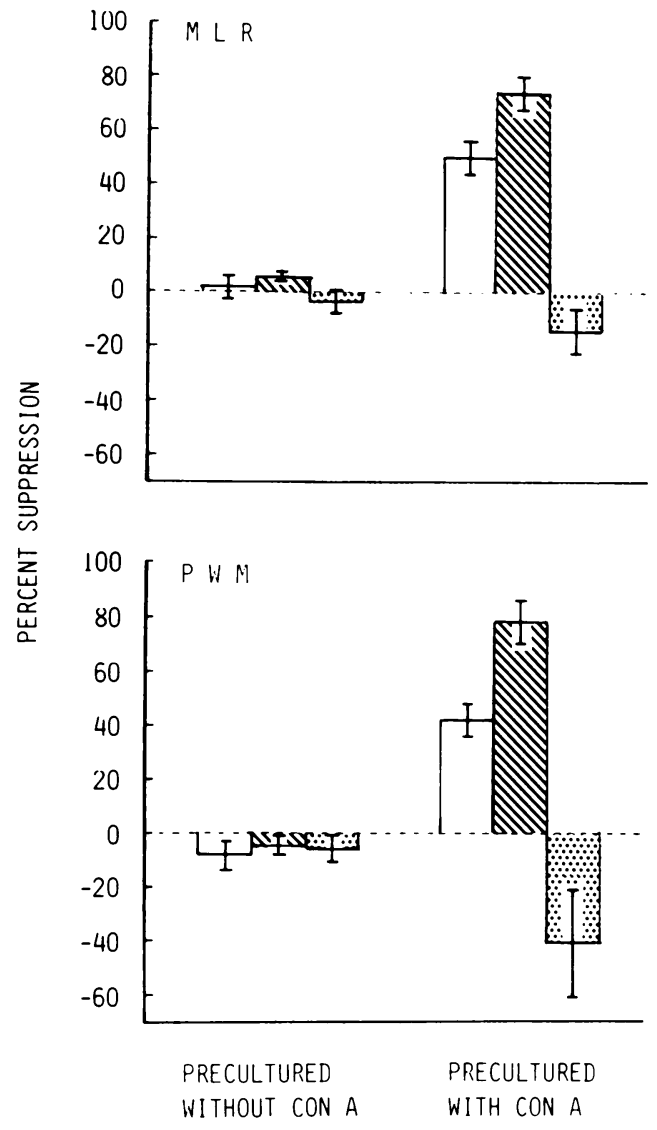

FIGURE 1 Differential suppressor activity of Con A-activated autorosetting and nonrosetting $\mathrm{T}$ cell populations from eight different normal individuals. Normal $\mathrm{T}$ cells that had been incubated with or without Con A, unfractionated or fractionated, were assayed for their suppressor activity in the test culture. The mean percent suppression and the range encompassed by $\pm 1 \mathrm{SE}$ is shown. $\square$, unfractionated T cell population; autorosetting $\mathrm{T}$ cell population; $\cdots$ rosetting $T$ cell population. activity seemed to be Con A dependent. As can be seen in Fig. 1, when Con A was omitted from culture medium, the $\mathrm{T}$ cells either fractionated or unfractionated failed to suppress both reactions. Con Aactivated autorosetting, but not nonrosetting $\mathrm{T}$ cells appear to be specific for the function of suppression.

Helper activity of Con A-activated T cells not forming autorosettes. To examine whether Con A-activated $\mathrm{T}$ cells not forming autorosettes might develop helper activity, fractionated $\mathrm{T}$ cells were added to cultures of B cells and stimulated with PWM. As shown in Fig. 2, the fresh $\mathrm{T}$ cells (Fig. $2 \mathrm{~B}$ ) or the $T$ cells, unfractionated or fractionated, that had been incubated for $60 \mathrm{~h}$ without Con A (Fig. $2 \mathrm{C}-\mathrm{E}$ ) expressed significant helper activity to roughly the same extent. The unfractionated $T$ cells that had been incubated with Con A could also act as helper cells but were not as effective as the first four $\mathrm{T}$ cell populations (Fig. $2 \mathrm{~F}$ ). The helper function of fractionated $\mathrm{T}$ cells was studied next. Con A-activated $\mathrm{T}$ cells forming autorosettes used as helper cells failed to help the PWM response of the B cells (Fig. 2 G). By removal of such $\mathrm{T}$ cells, helper activity was strongly revealed (Fig. $2 \mathrm{H}$ ). This helper activity was greater than the activity of fresh $\mathrm{T}$ cells (Fig. $2 \mathrm{~B}$ ) and of $\mathrm{T}$ cells precultured without Con A (Fig. $2 \mathrm{C}-\mathrm{E}$ ). Thus, Con $\mathrm{A}$ activation of human $\mathrm{T}$ cells can also induce helper activity; such helper activity could be masked in the unfractionated cell population by suppressor $T$ cell activity.

Relationship between Con A-induced suppressor T cell activities and Con A-induced autorosette levels. 14 normal individuals and 15 patients with various diseases were studied simultaneously for their Con Ainduced suppressor activities and the Con A-induced autorosette levels. As can be seen in Fig. 3, the degree of Con A-induced suppressor activity observed in lymphocytes from individual donors correlated well with the levels of Con A-induced autorosette-forming cells $(r=0.84)$. Each case that was defective with regard to Con A-induced suppressor activity also had a low level of Con A-induced autorosetting cells, whereas lymphocytes from the rest of studied donors demonstrated normal activity for both functions. These results provide further evidence that rosette formation with autologous RBC is a suitable surface marker of Con A-induced suppressor cells.

Surface phenotypic markers of Con A-activated T cell subpopulations. Con A-activated T cell populations, unfractionated or fractionated, were analyzed by the use of monoclonal antibodies and indirect immunofluorescence with the fluorescence microscope. As shown in Table I, 94\% of the unfractionated population was reactive with the OKT3 monoclonal antibody, $59 \%$ were reactive with OKT 4 , and $33 \%$ were reactive with OKT8. The autorosetting population and 

A. NO CELLS ADDED
B. FRESH T CELLS
C. UNFRACTIONATED T CELLS PRECULTURED WITHOUT CON A
D. AUTOROSETTING T CELLS PRECULTURED WITHOUT CON A
E. NONROSETTING T CELLS PRECULTURED WITHOUT CON A
F. UNFRACTIONATED T CELLS PRECULTURED WITH CON A
G. AUTOROSETTING T CELLS PRECULTURED WITH CON A
H. NOMROSETTING T CELLS PRECULTURED WITH CON A

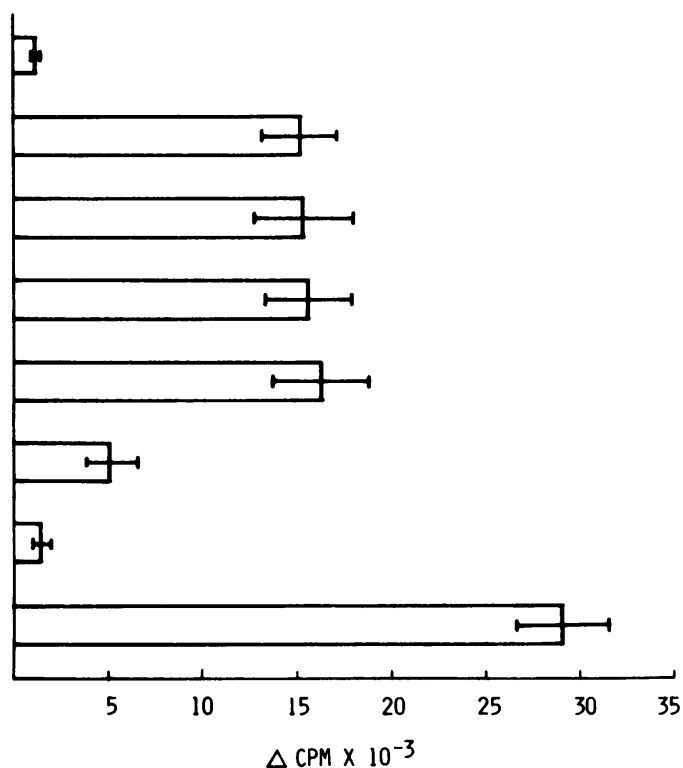

FIGURE 2 Helper activity by Con A-activated T cells not forming autorosettes from six different normal individuals. T cells were incubated for $60 \mathrm{~h}$ with or without Con $A$, and then fractionated into $\mathrm{T}$ cells forming autorosettes and those not forming autorosettes. Fractionated cells were added to test cultures containing responder $B$ cells and PWM. The mean response $\pm 1 \mathrm{SE}$ is shown. Response was significantly higher in group $\mathrm{B}, \mathrm{C}, \mathrm{D}, \mathrm{E}, \mathrm{F}$, or $\mathrm{H}(P<0.05)$ compared with group $\mathrm{A}$ or G. Response of group $\mathrm{F}$ was significantly lower $(P<0.005)$ compared with group B, C, D, E, or $\mathrm{H}$. Response of group $\mathrm{H}$ was significantly higher $(P<0.005)$ compared with the other groups. There was no significant difference among the responses of groups B, C, D, and E, nor a significant difference between the responses of groups $A$ and $G$.

nonrosetting population were similar to the unfractionated $\mathrm{T}$ cell population with respect to reactivity with the OKT3, OKT4, and OKT8 antibodies (Table I). Isolation of either autorosetting or nonrosetting $T$ cell subset provided no significant enrichment for the $\mathrm{OKT}^{+}$or $\mathrm{OKT}^{+}$population. In support of this ob-

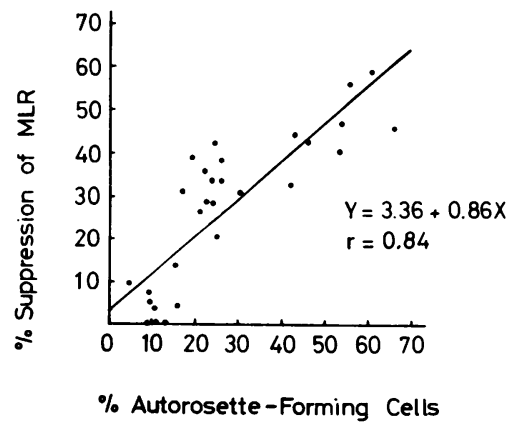

Figure 3 Relationship between Con A-induced suppressor activities and Con A-induced autorosette levels. Con Aactivated $\mathrm{T}$ cells were divided into two portions for either counting the autorosettes or for evaluating their suppressive ability in the MLR. servation were the reciprocal studies that demonstrated that $\mathrm{OKT}_{4}{ }^{+} \mathrm{T}$ cell-depleted and $\mathrm{OKT} 8^{+} \mathrm{T}$ celldepleted populations obtained by the treatment of unfractionated Con A-activated T cells with monoclonal antibodies plus complement were not enriched for the cells forming autorosettes (data not shown).

To determine the relationship of separated Con Aactivated $\mathrm{T}$ cell subsets to the $\mathrm{T} \gamma$ cell population, unfractionated $\mathrm{T}$ cells or autorosetting and nonrosetting $\mathrm{T}$ cell subsets were rosetted with IgG-coated ox RBC. These three populations were all comparable in their percentage of $\mathrm{T} \gamma$ cells (Table I).

Several studies in mice have demonstrated that Con A-induced suppressor cells express receptors for PNA $(8,9)$. To determine whether the Con A-activated human suppressor $T$ cells also have such receptors, Con A-activated $\mathrm{T}$ cell subsets were examined after staining with a fluorescein-labeled PNA. As shown in Table I, almost all of autorosetting cells that exert suppressive effects on the immune response were stained strongly with fluorescein-labeled PNA. In contrast, very few nonrosetting cells that function as helper cells were stained with PNA. The results presented here indicate that the surface properties of 
TABLE I

Cell Surface Markers of Con A-activated T cell Subpopulations

\begin{tabular}{lcccrr}
\hline \multicolumn{1}{c}{ Fraction } & OKT3 $^{+}$ & OKT4 $^{+}$ & OKT $8^{*}$ & \multicolumn{1}{c}{ T $\gamma$} & \multicolumn{1}{c}{$\begin{array}{c}\text { PNA receptor } \\
\text { positive }\end{array}$} \\
\hline & & & $\%^{*}$ & & \\
Unfractionated $\$$ & $94.3 \pm 1.1$ & $58.5 \pm 4.5$ & $32.6 \pm 5.0$ & $13.2 \pm 3.3$ & $35.0 \pm 4.2$ \\
Autorosetting $\ddagger$ & $96.8 \pm 1.7$ & $59.8 \pm 3.9$ & $37.5 \pm 5.3$ & $9.0 \pm 4.2$ & $93.6 \pm 2.5$ \\
Nonrosetting $\ddagger$ & $97.9 \pm 1.4$ & $60.5 \pm 2.3$ & $31.8 \pm 1.4$ & $14.6 \pm 3.8$ & $7.3 \pm 4.4$ \\
\hline
\end{tabular}

* Each value represents mean percentage of positive cells $\pm 1 \mathrm{SE}$ in the Con A-activated $\mathrm{T}$ cell subpopulations from five normal individuals.

\$ These unfractionated and fractionated $T$ cell populations originated from Con A-activated $\mathrm{T}$ cells. No cells of any fraction were reactive with OKT6 antibody that defines immature $\mathrm{T}$ cells $(20)$.

Con A-induced human suppressor $\mathrm{T}$ cells are similar to those of Con A-induced murine suppressor cells.

\section{DISCUSSION}

In view of the complexity of human $\mathrm{T}$ cell functions in the regulation of the immune response, we attempted to apply a technique of autorosette formation to isolate Con A-activated autorosetting and nonrosetting cell populations and to study their mode of action separately. The results in this report indicate that autorosette technique is a useful tool for separating and analyzing the $\mathrm{T}$ cell subpopulations examined here. The experiments presented show that Con A-induced helper and suppressor activities are mediated by two distinct subpopulations of $\mathrm{T}$ cells separable by such autorosette technique. In a culture of peripheral blood T cells with Con A for $60 \mathrm{~h}$, suppressor activity is an exclusive function of a population forming autorosettes, whereas a population not forming autorosettes exhibits helper activity. The identification of Con A-induced suppressor T cells on the basis of their capacity to bind autologous RBC has considerable clinical importance. Indeed, the degree of Con A-induced suppressor cell activity correlates well with autorosetting cell levels in the Con A-activated T cells. This autologous RBC rosette technique also appears to be a more rapid and simple tool for analyzing immunoregulatory status of individual patients.

It has been demonstrated in mice that $\mathrm{T}$ cells are composed of two functionally distinct cell populations, $T_{1}$ and $T_{2}$ cells at different maturation stages (10). Evidence has also been provided that $T_{1}$ cells are immature cells that have a low sialic acid content on the surface (11) and correspond to suppressor T cells (12, 13), and that $T_{2}$ cells consist of helper $T$ cells that have abundant sialic acid residues on the surface (12-14). Imai et al. (8) have found that when Con A- activated murine $T$ cells can be separated by using fluorescein-labeled PNA (which binds preferentially to $\beta$-galactosyl residues such as D-galactosyl- $\beta(1 \rightarrow 3)$ $N$-acetyl-D-galactosamine or D-galactosyl- $\beta(1 \rightarrow 3)-N$ acetyl-D-glucosamin on the cell surface, not masked by sialyl residues) into two fractions with the aid of a fluorescence-activated cell sorter, only the cell fraction stainable with PNA possesses the suppressive effect on the immune response. In human $T$ cells, there appears to be an analogous situation; previous studies of our own (15), as well as those of others $(4,16)$ have shown that an appreciable fraction of human thymocytes has receptors for both autologous RBC and PNA, whereas very few human peripheral blood $T$ cells bind the RBC and PNA unless pretreated with neuraminidase. These observations suggest that during $\mathrm{T}$ cell maturation, the cell surface of $\mathrm{T}$ cells is masked by sialic acid $(15,16)$, and that a low content of sialic acid on the cell surface may be important in the $\mathrm{T}$ cell reaction with autologous $\mathrm{RBC}$ (15). In this study, we have demonstrated that the Con A-activated autorosetting $T$ cells (which exert the suppressive effect), not the nonrosetting $T$ cells (which act as helper cells), can be stained with fluorescein-labeled PNA, indicating that Con A-induced human suppressor $\mathrm{T}$ cells also possess abundant $\beta$-galactosyl residues exposed on the cell surface, not masked by sialic acid. Thus, the cell surface properties of Con A-induced human suppressor cells may be considered analogous to those of Con A-induced murine suppressor cells.

Recently, Paracios et al. (17) found that fresh peripheral blood $\mathrm{T}$ cells capable of forming autorosettes can proliferate vigorously in response to autologous B cells. Moreover, the T cell population responsive to autologous $B$ cells has been shown to be particularly enriched in cells that are needed to generate Con A-induced suppressor function $(18,19)$. In this study, we have observed that Con A-induced autorosetting $\mathrm{T}$ cells are able to act as suppressor cells. 
Fresh $\mathrm{T}$ cells capable of forming autorosettes and Con A-activated $\mathrm{T}$ cells forming autorosettes appear to be intimately related and may belong to the same cell lineage.

More recently, monoclonal antibodies directed at subsets of human $T$ cells have been available to identify and separate helper cells from suppressor cells; OKT4 antibody has been shown to react with $55-60 \%$ of resting peripheral $\mathrm{T}$ cells, representing the human inducer (helper) population (20), whereas OKT8 antibody reacts with $\sim 20$ to $30 \%$ of $\mathrm{T}$ cells, with cytotoxic/suppressor function (21). Our attempt to clarify the relation of $\mathrm{T}$ cell subsets defined by the monoclonal antibodies to those defined by the autorosette technique has shown that Con A-activated autorosetting and nonrosetting $\mathrm{T}$ cell populations contain both $\mathrm{OKT} 4^{+}$and $\mathrm{OKT} 8^{+}$populations and are similar to the activated, but not the fractionated $\mathrm{T}$ cell population. Con A-induced autorosetting $\mathrm{T}$ cells have the receptors for PNA as observed in Con A-induced murine suppressor cells. Moreover, resting peripheral blood $\mathrm{T}$ cells only contain $\sim 3 \%$ autorosetting cells, whereas OKT 8 antibody is found in $\sim 20-30 \%$ of the peripheral blood $\mathrm{T}$ cells. These observations suggest that several $\mathrm{T}$ cell types would act as mediators of suppression (22); separate cell groups would be, for instance, involved in the suppression induced by Con $A$ and spontaneous suppression. The short-lived suppressor cells could play an important role in the spontaneous suppression, whereas the relatively longlived suppressor cells could mediate the Con Ainduced suppression (23). It should be noted that the restrictive activity of $\mathrm{OKT}^{+}$cells in a suppressor cell population was originally found in spontaneous suppressor assays (20), and that the suppressive effect of autorosetting cells was observed in Con A-induced suppressor assay system. In support of this hypothesis, our unpublished observations have shown that $\mathrm{T}$ cells stimulated with Con A for $60 \mathrm{~h}$ and depleted of OKT4 ${ }^{+}$ cells or $\mathrm{OKT}^{+}$cells are still able to function as suppressor cells. Furthermore, Kaddish et al. (24) suggest that Con A-induced suppressor cells may mediate a major portion of this effect through interferon, however, how the non-Con A-induced suppressor cells mediate their control is not clear. Since comparisons of different suppressor cell assays are needed to evaluate the immune regulatory status of individual patients, identification of suppressor cells with the use of autorosette technique and monoclonal antibodies will contribute to the understanding of various diseases in which a defect in immune control mechanisms is present.

\section{ACKNOWLEDGMENT}

This work was supported in part by research grants from the Vascular Lesion of Collagen Disease Research Committee,
Autoimmune Disease Research Committee, and Behçet Disease Research Committee of Japan, Ministry of Welfare, and the Japan Medical Research Foundation, Tokyo, Japan.

\section{REFERENCES}

1. Tse, H., and R. W. Dutton. 1976. Separation of helper and suppressor $\mathrm{T}$ lymphocytes on a Ficoll velocity sedimentation gradient. J. Exp. Med. 143: 1199-1210.

2. Jandinski, J., H. Cantor, T. Tadakuma, D. L. Reavy, and C. W. Pierce. 1976. Separation of helper T cells from suppressor $\mathrm{T}$ cells expressing different Ly components. I. Polyclonal activation: suppressor and helper activities are inherent properties of distinct $\mathrm{T}$-cell subclasses. J. Exp. Med. 143: 1382-1390.

3. Sakane, T., and I. Green. 1977. Human suppressor T cells induced by concanavalin A: suppressor $\mathrm{T}$ cells belong to distinctive $\mathrm{T}$ cell subclasses. J. Immunol. 119: 11691178.

4. Fournier, C., and J. Charreire. 1978. Activation of a human $\mathrm{T}$ cell subpopulation bearing receptors for autologous erythrocytes by concanavalin A. J. Immunol. 121: 771776.

5. Sakane, T., A. D. Steinberg, J. P. Reeves, and I. Green. 1979. Studies of immune functions of patients with systemic lupus erythematosus. Complement-dependent immunoglobulin $\mathbf{M}$ anti-thymus-derived cell antibodies preferentially inactivate suppressor cells. J. Clin. Invest. 63: 954-965.

6. Lohrmann, H-P., L. Novikovs, and R. G. Graw, Jr. 1974. Cellular interactions in the proliferative response of human $\mathrm{T}$ and $\mathrm{B}$ lymphocytes to phytomitogens and allogeneic lymphocytes. J. Exp. Med. 139: 1553-1567.

7. Moretta, L., S. R. Webb, C. E. Grossi, P. M. Lydyard, and M. D. Cooper. 1977. Functional analysis of two human T-cell subpopulations. Help and suppression of B-cell responses by $\mathrm{T}$ cells bearing receptors for $\operatorname{IgM}$ or IgG. J. Exp. Med. 146: 184-200.

8. Imai, Y., Y. Oguchi, T. Nakano, and T. Osawa. 1979. Separation of mouse $T$ cell subsets by a fluorescent activated cell sorter using fluorescence-labeled peanut agglutinin. Immunol. Commun. 8: 495-503.

9. Nakano, T., Y. Imai, M. Naiki, and T. Osawa. 1980. Characterization of mouse helper and suppressor $\mathrm{T}$ cell subsets separated by lectins. J. Immunol. 125: 19281932.

10. Raff, M. C. 1971. Surface antigenic markers for distinguishing $\mathrm{T}$ and $\mathrm{B}$ lymphocytes in mice. Transplant. Rev. 6: 52-80.

11. Reisner, Y., M. Linker-Israeli, and N. Sharon. 1976. Separation of mouse thymocytes into two subpopulations by the use of peanut agglutinin. Cell. Immunol. 25: 129-134.

12. Gershon, R. K. 1974. T cell control of antibody production. In Contemporary Topics in Immunobiology. M. D. Cooper and N. L. Warner editors. Plenum Publishing Corporation, New York. 3: 1-40.

13. Nakano, T., Y. Oguchi, Y. Imai, and T. Osawa. 1980. Induction and separation of mouse helper $\mathrm{T}$ cells by lectins. Immunology. 40: 217-222.

14. Erb, P., B. Meier, D. Krause, H. von Boehmer, and M. Feldmann. 1978. Nature of T cell-macrophage interaction in helper cell induction in vitro. I. Evidence for genetic restriction of $\mathrm{T}$ cell-macrophage interaction prior to T cell priming. Eur. J. Immunol. 8: 786-792.

15. Honda, M., H. Kotani, and T. Sakane. 1981. Human T 
cells having receptors for autologous erythrocytes are suppressor precursors and those not having the receptors are amplifier cells. Fed. Proc. 40: 1140.

16. Reisner, Y., M. Biniaminov, E. Rosenthal, N. Sharon, and B. Ramot. 1979. Interaction of peanut agglutinin with normal human lymphocytes and with leukemic cells. Proc. Natl. Acad. Sci. U.S.A. 76: 447-45l.

17. Paracios, R., L. Llorente, D. Alarcón-Segovia, A. RuízArguelles, and E. Díaz-Jouanen. 1980. Autologous rosette-forming $T$ cells as the responding cells in human autologous mixed-lymphocyte reaction.J. Clin. Invest. 65: $1527-1530$.

18. Sakane, T., and I. Green. 1979. Specificity and suppressor function of human $\mathrm{T}$ cells responsive to autologous non-T cells. J. Immunol. 123: 584-589.

19. Innes, J. B., M. M. Kuntz, Y. T. Kim, and M. E. Weksler. 1979. Induction of suppressor activity in autologous mixed lymphocyte reaction and in cultures with concanavalin A. J. Clin. Invest. 64: 1608-1613.
20. Reinherz, E. L., and S. F. Schlossman. 1980. Regulation of the immune response: inducer and suppressor $\mathrm{T}$ lymphocyte subsets in human beings. N. Engl. J. Med. 303: 370-373.

21. Morimoto, C., E. L. Reinherz, S. F. Schlossman, P. H. Schur, J. A. Mills, and A. D. Steinberg. 1980. Alterations in immunoregulatory $\mathrm{T}$ cell subsets in active systemic lupus erythematosus. J. Clin. Invest. 66: 11711174.

22. Rice, L., A. H. Laughter, and J. J. Twomey. 1979. Three suppressor systems in human blood that modulate lymphoproliferation. J. Immunol. 122: 991-996.

23. Nussenblatt, R. B., S. J. Cevario, and I. Gery. 1980. Altered suppressor-cell activities in uveitis. Lancet. 11: $722-724$.

24. Kadish, A. S., F. A. Tansey, G. S. M. Yu, A. T. Doyle, and B. R. Bloom. 1980. Interferon as a mediator of human lymphocyte suppression. J. Exp. Med. 151: 637-650. 